\title{
Microstructure-Property Relationship of Polyurethane Foams Modified with Baltic Sea Biomass: Microcomputed Tomography vs. Scanning Electron Microscopy
}

\author{
Paulina Kosmela ${ }^{1, *}$, Jan Suchorzewski ${ }^{2,3}{ }^{(\mathbb{C}}$, Krzysztof Formela $^{1, *}{ }^{(\mathbb{C}}$, Paweł Kazimierski ${ }^{4}(\mathbb{D}$, \\ Józef Tadeusz Haponiuk ${ }^{1}$ (D) and Łukasz Piszczyk ${ }^{1}$ (D) \\ 1 Department of Polymer Technology, Faculty of Chemistry, Gdansk University of Technology, G. \\ Narutowicza 11/12, 80-233 Gdansk, Poland; jozhapon@pg.edu.pl (J.T.H.); lukpiszc@pg.edu.pl (Ł.P.) \\ 2 Division Built Environment, Department Infrastructure and Concrete Structures, Material Design, \\ RISE Research Institutes of Sweden, Brinellgatan 4, 501-15 Borås, Sweden; jan.suchorzewski@ri.se \\ 3 Department of Concrete Structures, Faculty of Civil and Environmental Engineering, Gdansk University of \\ Technology, G. Narutowicza 11/12, 80-233 Gdansk, Poland \\ 4 Institute of Fluid Flow Machinery, Fiszera Str. 14, 80-231 Gdansk, Poland; pkazimierski@imp.gda.pl \\ * Correspondence: paulina.kosmela@pg.edu.pl (P.K.); krzysztof.formela@pg.edu.pl (K.F.)
}

Received: 30 October 2020; Accepted: 10 December 2020; Published: 16 December 2020

\begin{abstract}
In this paper, novel rigid polyurethane foams modified with Baltic Sea biomass were compared with traditional petro-based polyurethane foam as reference sample. A special attention was focused on complex studies of microstructure, which was visualized and measured in 3D with high-resolution microcomputed tomography (microCT) and, as commonly applied for this purpose, scanning electron microscopy (SEM). The impact of pore volume, area, shape and orientation on appearance density and thermal insulation properties of polyurethane foams was determined. The results presented in the paper confirm that microcomputed tomography is a useful tool for relatively quick estimation of polyurethane foams' microstructure, what is crucial especially in the case of thermal insulation materials.
\end{abstract}

Keywords: rigid polyurethane foam; biopolyols; microcomputed tomography; scanning electron microscope; microstructure; pores; sustainable materials

\section{Introduction}

Polyurethane foam has multiple applications in water sports and other marine industries, carpentry and as sleeping mattress but mostly are used as thermal insulation. It is the world's sixth most used polymer with an annual production of 18 million tons [1]. Polyurethanes are one of the most widely used thermal insulation materials in buildings due to their very low thermal conductivity and relatively good mechanical performance in comparison with other popular thermal insulators like polystyrene and mineral wool. The standard value of thermal conductivity factor for PU foams is equal to $\lambda=0.020-0.027 \mathrm{~W} / \mathrm{m}^{2} \mathrm{~K}$, while the compressive strength $\sigma_{\mathrm{c}}$ is between $100-500 \mathrm{kPa}$ [2,3]. PU foams have disadvantages, like high vapor diffusion resistance factor $\mu=50-100$ and low fire resistance (up to $120^{\circ} \mathrm{C}$ ) [2,3]. The insulation materials, like polyurethanes, play an important role in the building industry as they determine long-term energy efficiency and sustainability.

In polyurethane industry, the use of renewable or waste materials, mainly various compounds containing hydroxyl groups like vegetable oils, which are commonly used in the formulation of polyurethane products. Depending on the geographical location, different types are used: rapeseed and 
sunflower oil in Europe, palm and coconut oil in Asia, and soybean oil in the North America [4-6]. Vegetable oils, which are currently one of the raw materials used in the production of polyols, dedicated for the production of polyurethane materials, are mainly basic components of the food industry. The introduction of oils as for the large-scale production of plastics could increase their prices and increase the costs of various types of food products. Therefore, the use of byproducts in the processing of renewable raw materials, such as biomass or waste glycerol, is currently gaining more attention [7-9]. During production of one ton of biodiesel, $90-110 \mathrm{~kg}$ of waste glycerol is produced with varying chemical composition [10]. Due to a large amount of produced byproduct in the form of glycerol waste, diverse solutions for its sustainable management have been developed [11,12]. Biomass is another example of a raw material used in the plastics industry. The number of reports on the use of various types of the biomass, not only as a source of renewable energy but also as a raw material for receiving, among others, rigid polyurethane foams is constantly increasing [13-15].

The most important renewable sources used in the plastics industry include biomass from wood, arable crops, and aquatic plants [16]. Potential biomass that can be used in the plastics industry is biomass from the aquatic environment (flowering plants and algae inhabiting water reservoirs). Biomass of algae contains large amounts of carbohydrates and small amounts of lignin, which makes algae an excellent candidate for the synthesis of bioplastics $[17,18]$. The use of algae for bioplastics can be carried out directly or indirectly. Direct methods include mixing polymers with algae biomass [19-22], and indirect methods use algae biomass to obtain a component for the synthesis of bioplastics [23-29].

The chemical modifications affect the PU foams microstructure and key macroscopic performance like thermal conductivity and mechanical strength. As the pore diameters in PU foams are very fine $(\mathrm{d}=0.02-0.06 \mathrm{~mm})$ it is extremely difficult to evaluate precisely their distribution with commonly applied methods like scanning electron microscopy and optical microscopy [30]. Recently, the application of high-resolution X-ray microcomputed tomography (microCT) has increased significantly. MicroCT is a nondestructive 3D imaging technique. The basic physical X-ray principal of computed tomography is the interaction of ionizing radiation with the material, where the so-called photoeffect builds the main interaction mechanism. As an X-ray beam penetrates an object, it is exponentially attenuated according to the material along its path. The energy-dependent material constant appearing in the exponent of this attenuation formula is called the linear attenuation coefficient. It expresses the amount of radiation that is attenuated on an infinitely small distance, in which the final attenuation reflects the sum of all these local linear attenuations along the $X$-ray beam. Therefore, an X-ray projection (or X-ray image) represents an image of the sum of all local attenuations along the X-ray beam. The 3D images of the interior of an object are obtained by collecting a series of 2D images that are stored while the sample is rotated. With the development of microCT, complementary techniques as well as new image processing algorithms and analysis techniques have evolved. These unique techniques opened the field of microCT to many new applications. Imaging techniques with image analysis offer the possibility to analyze the size and shape of each individual particle present in a sample. In these methods, touching particles are separated, so that each individual particle can be identified, counted and measured. The powerful imaging capabilities of X-ray tomography are now available in a range instruments suitable for microscopic imaging of small objects with a wide range of applications such as 3D biomedical [31,32], food studies [33], soft tissue research [34,35], insects and fishes, microelectronics, geological studies [36,37] including porous rocks for oil recovery purposes, cementitious materials [38-40] and wood structure after pyrolysis [41]. X-ray microcomputed tomography has been recently often used as a powerful tool for analysis of polyurethane foams. Patterson et al. [42] were particularly interested in compressive and tensile response of PU foams and differences in molding shapes (block and conical). They investigated deformed specimens, finding shear band zones connected usually with presence of larger pores. PU foams modified with glass microspheres (syntactic foams) structure were investigated by Adrien et al. [43]. They found strong dependency of failure type on matrix type (soft or rigid foam). For PU soft matrix, the hollow microspheres (pore like structures) with lower radius and skin thickness were mainly broken in compression, while for rigid PU 
matrix their exhibit opposite behavior. McDonald et al. [44] performed one of the first microCT scans of polymeric conventional and auxetic PU foams under load (uniaxial tension) analyzing their internal structure evolution. They observed severe changes in the foam density and internal structure. Similar study was performed for PU foams by Youssef et al. [45], where the internal foams microstructure was exported to FEM 3D model. The clear influence of pore structure on material failure was observed. With use of microCT, it was proven that natural origin additives (oak quercus robur bark) decrease the water absorption, thermal conductivity, brittleness, aging in PU foams with low cost by changing the pore structure [46].

The main objective of this paper is a comprehensive investigation of novel rigid polyurethane foam modified with Baltic Sea biomass (biopolyol from liquefied marine environment biomass: Enteromorpha and Zostera marina) as a possible sustainable material for building industry. A 3D microstructure analysis with a high-resolution microcomputed tomography system (microCT) of modified foams in comparison with traditional petro-based polyurethane was performed. Moreover, microstructure was also examined using SEM in order to comparison with microCT analysis. The influence of pores volume, area, shape and orientation on apparent density and thermal insulation properties were evaluated.

\section{Materials and Methods}

\subsection{Materials}

Rigid polyurethane (PU) foams were obtained using the biopolyol LB (liquefaction biopoliol) synthesized in our laboratory and Rokopol ${ }^{\circledR}$ RF551 petrochemical polyol (a polyoxyalkylene multihydroxyls alcohol) from PCC Group. The selected properties of polyols are shown in Table 1. The biopolyol LB was obtained in the biomass liquefaction process, which included: 10 wt.\% macroalgae of Enteromorpha and $90 \mathrm{wt}$ \% of seagrass (Zostera marina), originating in the Baltic Sea. As a solvent for the liquefaction process, purified waste glycerol containing 99\% obtained from the company Bio-Chem Sp. z o.o. (Olszanka, Poland) and poly(ethylene oxide) (PEG400) from Avantor Performance Materials Poland S.A. (Gliwice, Poland) were used. During the liquefaction, sulfuric acid (VI) as a catalyst and sodium hydroxide (both reagents from Avantor Performance Materials Poland S.A. (Gliwice, Poland) were used to neutralize biopolyols. The detailed information about reaction conditions are presented elsewhere [47]. As an isocyanate component, the polymeric $4,4^{\prime}$-methylene diphenyl diisocyanate (pMDI) with a free NCO content of 31.5\% from BASF (Ludwigshafen, Germany) was applied. The catalysts used were: $33 \mathrm{wt} \%$ potassium acetate solution in ethylene glycol-PC CAT $^{\circledR}$ TKA30 from Performance Chemicals (AC) (Buchholz in der Nordheide, Germany), 75\% wt. potassium octoate solution in diethylene glycol—Dabco K15, $33 \mathrm{wt}$ \% solution of triethylenediamine in dipropylene glycol-Dabco33LV from Air Products (Allentown, PA, USA and dibutyltin dilaurate (DBTDL) from Sigma Aldrich (Saint Louis, MO, USA). Tegostab B 8465 from Evonik Industries AG (Essen, Germany) was used as a stabilizer of the porous structure (SPC), and n-pentane from Sigma Aldrich (Saint Louis, MO, USA) was used as a blowing agent. Tris(chloropropyl) phosphate (TCCP) was also added as a flame retardant, which further reduced the viscosity of the polyol mixture from LANXESS Deutschland GmbH (Koln, Germany).

Table 1. Selected properties of polyols used to obtain polyurethane (PU) foams.

\begin{tabular}{cccc}
\hline Polyol & $\mathrm{L}_{\mathrm{OH}}\left(\mathbf{m g}_{\mathrm{KOH}} / \mathrm{g}\right)$ & $\eta(\mathbf{m P a} \cdot \mathbf{s})$ & $\rho\left(\mathrm{g} / \mathrm{cm}^{\mathbf{3}}\right)$ \\
\hline LB & 650 & 2236 & 1.21 \\
Rokopol ${ }^{\circledR}$ RF551 & 440 & $3000-5000$ & 1.06 \\
\hline
\end{tabular}

\subsection{Synthesis of Rigid PU Foams}

Rigid PU foams were obtained using the one-step method from a two-component system. The isocyanate index ( $\mathrm{I}_{\mathrm{ISO}}$ ) has been selected based on literature reports [48-50] and it was 200 or 300. Component A was a polyol mixture consisting of Rokopol ${ }^{\circledR}$ RF551 polyol and biopolyol LB, catalysts, 
surfactant, flame retardant and a blowing agent. Component B was an isocyanate. Foam formulations are presented in Table 2. Both components were mixed in a polypropylene cup with a mechanical agitator at a speed of $2000 \mathrm{rpm}$, poured into an open mold and heated for $24 \mathrm{~h}$ at $60{ }^{\circ} \mathrm{C}$.

Table 2. The compositions of rigid polyurethane foams.

\begin{tabular}{ccccc}
\hline \multirow{2}{*}{ Raw Materials (pbw) } & \multicolumn{4}{c}{ Foam Symbol } \\
\cline { 2 - 5 } & 200LB0 & 200LB30 & 300LB0 & 300LB30 \\
\hline Rokopol RF551 & 100 & 70 & 100 & 70 \\
Biopoliol LB & 0 & 30 & 0 & 30 \\
AC & 0.5 & 0.5 & 0.5 & 0.5 \\
Dabco 15K & 0.5 & 0.5 & 1 & 1 \\
Dabco 33LV & 0.5 & 0.5 & 0.5 & 0.5 \\
DBTDL & 0.5 & 0.5 & 0.5 & 0.5 \\
TEGOSTAB B 8465 & 6 & 6 & 6 & 6 \\
TCCP & 10 & 10 & 10 & 10 \\
n-pentane & 12.5 & 12.5 & 20 & 20 \\
pMDI & 203.6 & 237.0 & 305.3 & 355.4 \\
\hline
\end{tabular}

\subsection{Methods}

\subsubsection{Apparent Density}

The apparent density was determined in accordance with ISO 845. The mass of the samples was determined using an analytical balance with an accuracy of $0.1 \mathrm{mg}$, and the volume was determined after dimensioning the rolls using an electronic caliper with an accuracy of $0.1 \mathrm{~mm}$.

\subsubsection{Thermal Conductivity}

The thermal conductivity of the foams was tested in accordance with ISO 8301 standard using the Holometrix 2300. The average temperature of analysis was $10^{\circ} \mathrm{C}$, temperatures of lower and upper plates 0 and $20^{\circ} \mathrm{C}$, respectively. Three samples with size of $300 \times 300 \times 50 \mathrm{~mm}$ were tested for each composition. Thermal resistance is closely related to the conductivity coefficient $(\lambda)$ and depends on the thickness of the material $(d)$, as presented in Equation (1):

$$
R=\frac{d}{\lambda}
$$

\subsubsection{Scanning Electron Microscopy}

The cell morphology of polyurethane samples was investigated with a Quanta FEG 250 environmental scanning electron microscope (SEM) (FEI Company, Hillsboro, OR, USA) using an acceleration of $25 \mathrm{kV}$. The average value of pore diameter was calculated based on SEM images in ImageJ. The result was obtained from averaging 100 measurements.

\subsubsection{Microcomputed Tomography}

To study the internal structure of polyurethane foams and its relation with global material properties each specimens with diameter $d=15 \mathrm{~mm}$ and height $h=15-25 \mathrm{~mm}$ were scanned in microCT. Specimens were scanned by means of the 3D X-ray microtomograph Skyscan 1173 (Bruker, Kontich, Belgium) [51,52]. X-ray microtomography (called microCT or $\mu \mathrm{CT}$ ) is a 3D imaging technique which uses $X$-rays to create cross-sections of a physical object that is used to recreate a virtual model (3D model) without destroying the original object. The X-ray microtomograph used in this research represents a new generation in high-resolution desktop X-ray microtomography systems [38,51]. The scans were completed to ten times faster with the same resolution and image quality as compared to previous microCT with a fixed source-detector design. The scanner was equipped with the newly developed 
$130 \mathrm{keV}$ microfocus X-ray source with a very stable focal spot position and flat panel sensor of a large format (5 Mpx) with a special protection by a lead-glass fiber-optic window. As compared to usual X-ray microtomographs, this scanner has two basic advantages: (a) large specimens up to $150 \mathrm{~mm}$ in diameter may be scanned and (b) specimens are scanned with a higher precision (2-3 microns).

The specimens were scanned with resolution of $9 \mu \mathrm{m}$, by rotation of $180^{\circ}$. An X-ray voltage energy of $35 \mathrm{keV}$ and current of $175 \mu \mathrm{A}$ and exposure time of $500 \mathrm{~ms}$ was found to give sufficient contrast for the weakly absorbing polymeric foam material. The wavelength profile of the beam was shaped using no filter, placed just in front of the exit window of the X-ray source. The specimen was scanned with rotation step of $0.2^{\circ}$ for high image precision. Moreover, frame averaging 4 and random movement 10 was used. Then the scans were reconstructed into 3D tomographical volumes using Skyscan Nrecon 1.6.9.8 software (Bruker, Kontich, Belgium), with ring artefact correction at level of 8 and smoothing level 6. Reconstructed images were analyzed in Skyscan CTAn 1.17.7.2 software(Bruker, Kontich, Belgium), and all steps of analysis are summarized in Figure 1. At first step, the images filtering function was used to sharpen the images (Figure 1a). Then, a threshold of 60-255 was applied (Figure 1b). The technical difficulties in microCT scanning of low-density foams, like polyurethane, were reported due to its relatively low attenuation coefficient [52]. These difficulties may be overcome by specimen preparation with contrast agents [52] or with image postprocessing [53]. In this paper the second approach was chosen. The option of watershed operations of anisotropic diffusion was used to reassemble broken objects (pores) (Figure 1c) in the image. At the end black and white pixels smaller than $25 \mu \mathrm{m}$ was applied. The volume used for analysis was limited to $d=10 \mathrm{~mm}$ and $h=10 \mathrm{~mm}$, due to very high analysis time of micropores. The whole specimens consisted of around 1,500,000 pores.
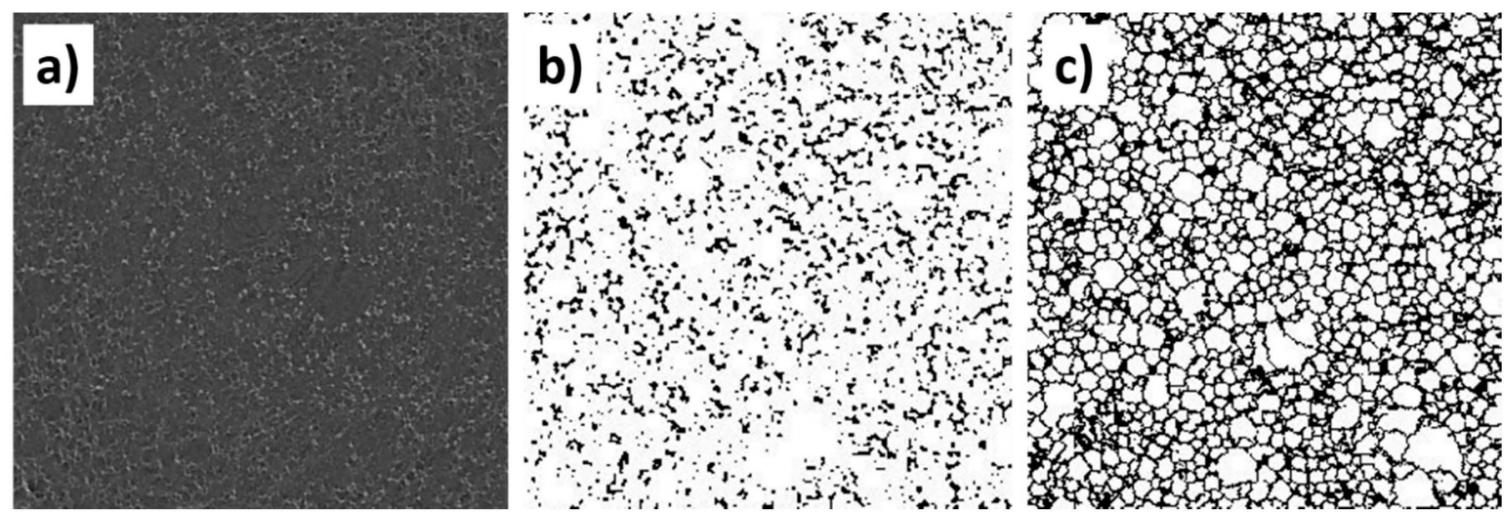

Figure 1. Microtomography (microCT) scan postprocessing: (a) reconstructed scan, (b) scan after threshold and (c) image after anisotropic diffusion.

\section{Results and Discussion}

\subsection{Microcomputer Tomography}

The internal structure of specimens was analyzed both qualitatively and quantitatively. Based on the preliminary results, in this work, the most differing specimens coded as 200LB0, 200LB30 and 300LB0, 300LB30 were investigated. The images of 3D internal structure for $\mathrm{I}_{\mathrm{ISO}}=200$ and $\mathrm{I}_{\mathrm{ISO}}=300$ with different amounts of biopolyols are presented at Figure 2. Depending on the type of foam, the increase in the isocyanate content resulted in the formation of pores with a less spherical shape (for foams with $0 \mathrm{wt}$ \% biopolyol) and a more spherical shape (for foams with $30 \mathrm{wt}$ \% biopolyol). The addition of biopolyols from sea biomass caused a decrease of pore size for both isocyanate contents, while the apparent density remained constant and thermal conductivity decreased (see Table 3). A similar microstructural effect of pore diameters decrease was observed when other organic biopolyols (from oak bark) were added to polyurethane foams [46]. 


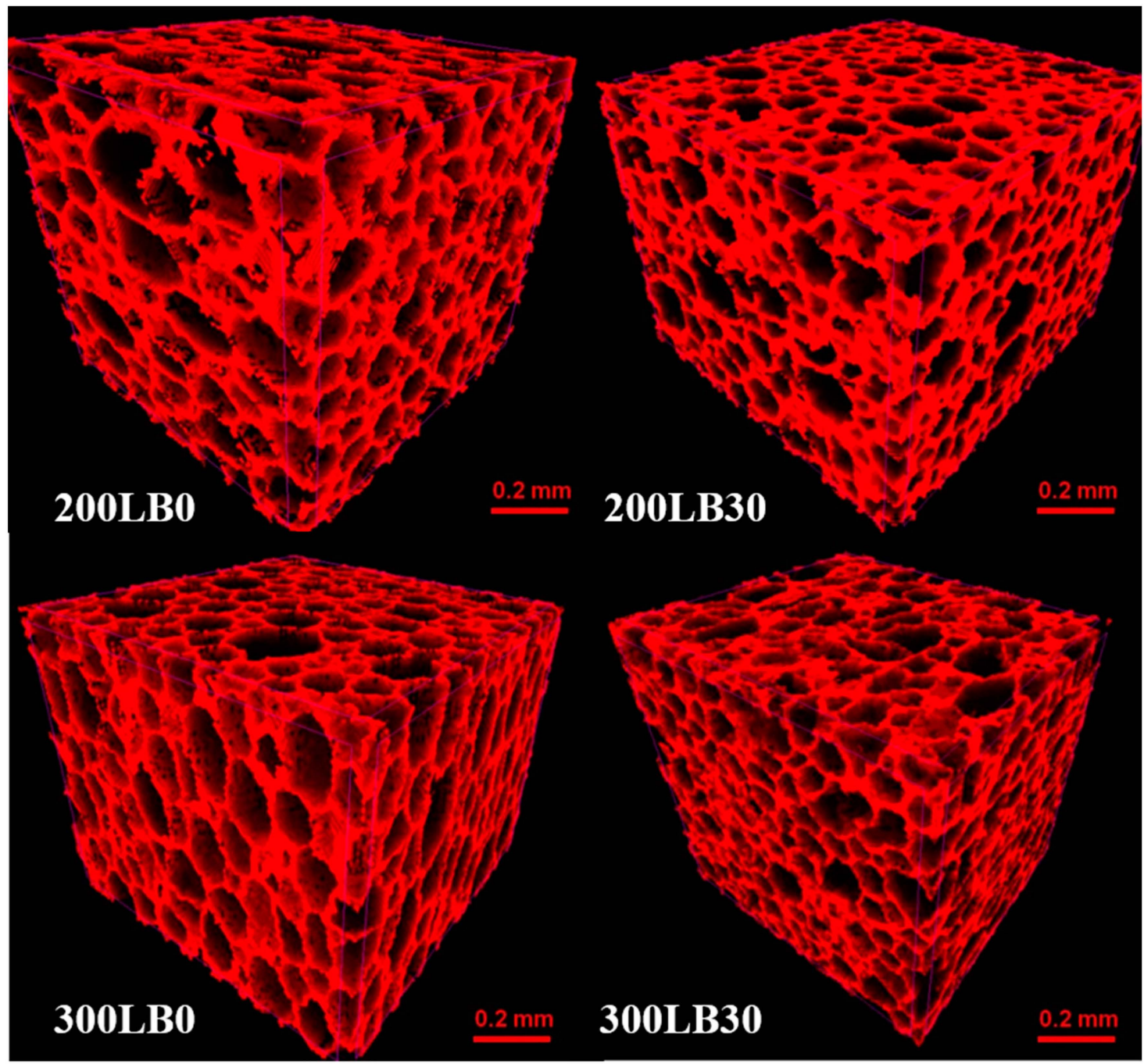

Figure 2. 3D images of foams skeletons and pores for PU foams.

Table 3. Average pore diameter values and thermal insulation properties of the obtained foams.

\begin{tabular}{|c|c|c|c|c|c|}
\hline Foam Symbol & $\begin{array}{c}\text { Apparent } \\
\text { Density } \\
\left(\mathrm{kg} / \mathrm{m}^{3}\right)\end{array}$ & $\begin{array}{c}\text { Pore } \\
\text { Diameter } \\
\text { SEM }(\mu \mathrm{m})\end{array}$ & $\begin{array}{c}\text { Pore } \\
\text { Diameter } \\
\text { MicroCT } \\
(\mu \mathrm{m})\end{array}$ & $\begin{array}{l}\text { Coefficient of } \\
\text { Thermal } \\
\text { Conductivity } \\
(\mathrm{W} / \mathrm{m} \cdot \mathrm{K})\end{array}$ & $\begin{array}{c}\text { Thermal } \\
\text { Resistance } \\
(\mathrm{d}=0.02 \mathrm{~m}) \\
\left(\mathrm{m}^{2} \cdot \mathrm{K} / \mathrm{W}\right)\end{array}$ \\
\hline 200_LB0 & $49.2 \pm 1.8$ & $147 \pm 26$ & $117 \pm 21$ & 0.0270 & 0.741 \\
\hline 200_LB30 & $49.6 \pm 1.3$ & $179 \pm 25$ & $108 \pm 22$ & 0.0246 & 0.810 \\
\hline 300_LB0 & $49.9 \pm 2.2$ & $176 \pm 30$ & $131 \pm 25$ & 0.0261 & 0.767 \\
\hline 300_LB30 & $52.1 \pm 1.2$ & $191 \pm 38$ & $124 \pm 17$ & 0.0248 & 0.806 \\
\hline
\end{tabular}

The pores' geometrical properties in each specimen were measured considering parameters like pore sphericity (Figure 3), orientation (inclination angle) (Figure 4), volume (Figure 5), and surface (Figure 6). 

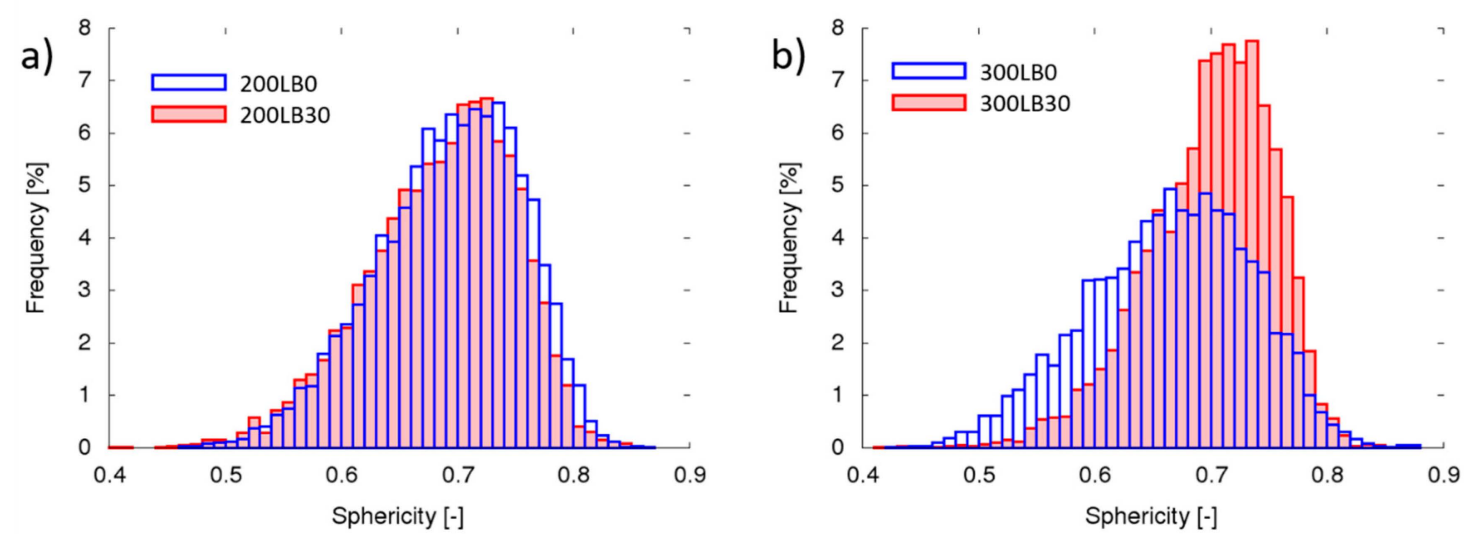

Figure 3. Pore sphericity for samples prepared with: (a) $\mathrm{I}_{\mathrm{ISO}}=200$ and (b) $\mathrm{I}_{\mathrm{ISO}}=300$.
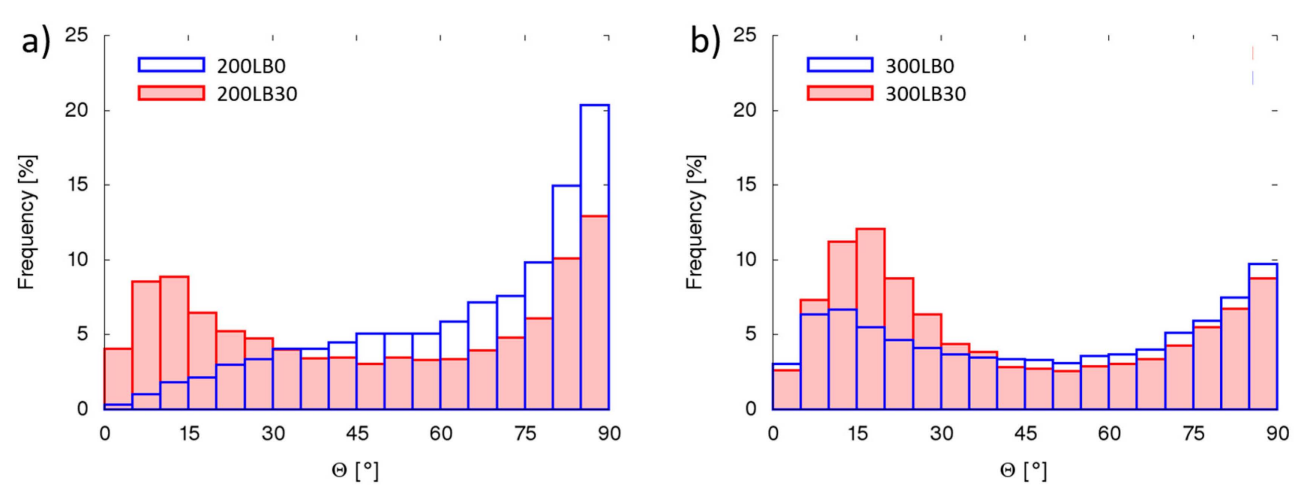

Figure 4. Pores vertical inclination angle $\Theta$ for $(\mathbf{a}) \mathrm{I}_{\mathrm{ISO}}=200$ and $(\mathbf{b}) \mathrm{I}_{\mathrm{ISO}}=300$.
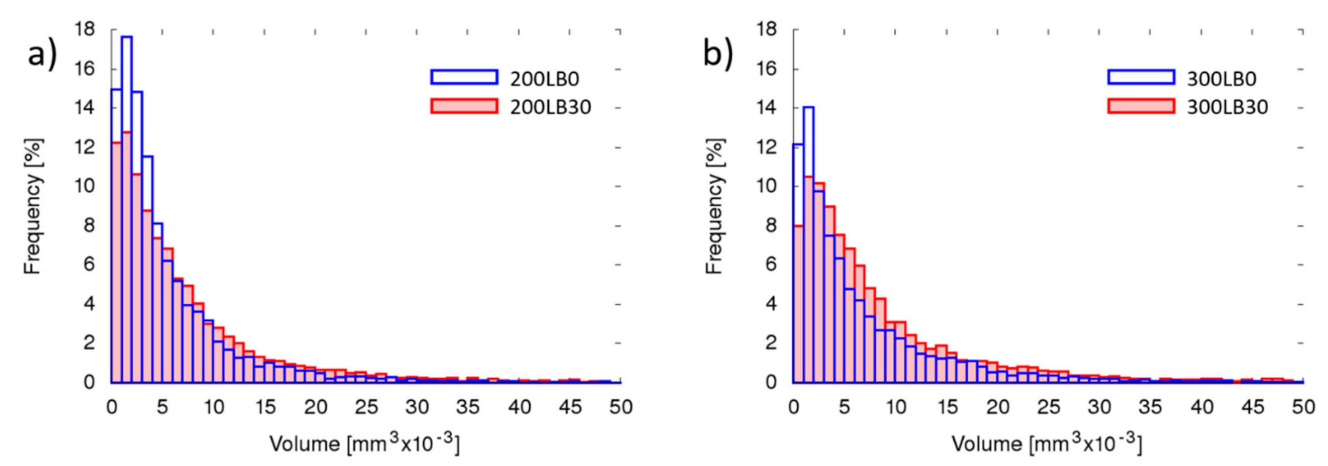

Figure 5. Pores volume for (a) $\mathrm{I}_{\mathrm{ISO}}=200$ and (b) $\mathrm{I}_{\mathrm{ISO}}=300$.
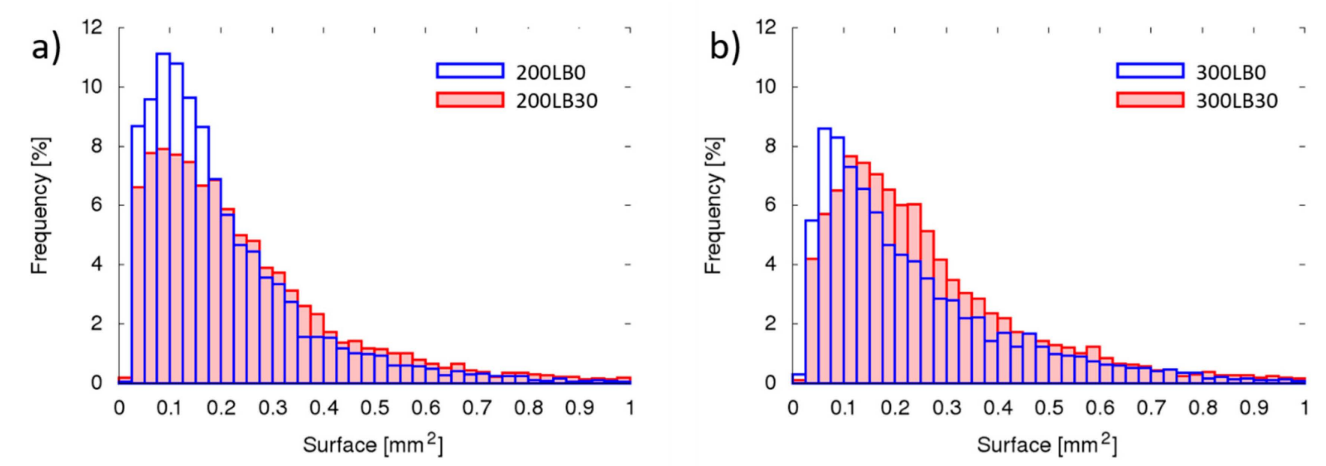

Figure 6. Pores' external surface area for (a) $\mathrm{I}_{\mathrm{ISO}}=200$ and (b) $\mathrm{I}_{\mathrm{ISO}}=300$. 
The sphericity $\psi$ is a dimensionless parameter describing how closely the analyzed object approaches the mathematically ideal sphere and can be calculated with the following equation (Equation (2)):

$$
\Psi=\frac{\pi^{\frac{1}{3}} \times\left(6 \times V_{p}\right)^{\frac{2}{3}}}{A_{p}}
$$

where $V_{p}$ represents object volume, $A_{p}$ is the object surface. Therefore, for perfect sphere sphericity $\psi=1$, for tetrahedron $\psi=0.671$ and for infinite straight line $\psi=0$ [54]. The sphericity measured for foam cells with $\mathrm{I}_{\mathrm{ISO}}=200$ was similar with and without biopolyol and was scattered from $\psi_{\min }=0.40$ to $\psi_{\max }=0.86$ with average $\psi_{\text {avg }}=0.72$, whereas for $\mathrm{I}_{\mathrm{ISO}}=300$ in similar range the distribution with and without biopolyol was different (Figure 3). For foam LB $=30 \%$ average sphericity was $\psi_{\text {avg }}=0.74$ and without biopolyol admixtures $\psi_{\text {avg }}=0.69$. Moreover, the pores in foam with biopolyol had less concentrated distribution of sphericity (over $66 \%$ of pores had sphericity in the range $0.69<\psi<0.77$ for $\mathrm{LB}=30 \%$, while for $\mathrm{LB}=0 \% 0.58<\psi<0.75$ ).

Many works report anisotropic behavior of polyurethanes, with usually greater mechanical strength in direction of foam growth [43-45]. This phenomenon is connected with internal structure. As the foams grow in the form vertically, they usually have an oval shape (elliptical in section) with the semimajor axis in vertical direction. The following phenomenon may be measured in microCT scans as the orientation of the object's major axis inclination to vertical axis $\Theta$. Angle $0^{\circ}$ means that the major axis (basing on the moment of inertia) is perfectly vertical, while $90^{\circ}$ means fully horizontal. For foams with $\mathrm{I}_{\mathrm{ISO}}=200$, the biopolyol addition caused more equal orientation distribution with peaks in vertical (25\%) and horizontal (29\%) orientation, while without biopolyol $47 \%$ of pores where oriented horizontally between $75-90^{\circ}$. This behavior may be the result of horizontal interconnection of single pores. For foams with $\mathrm{I}_{\mathrm{ISO}}=300$ the presence of biopolyol caused again more smooth distribution of orientation, while original polyurethane had pores with vertical orientation $\left(47 \%\right.$ in the range $\left.0-30^{\circ}\right)$. The result clearly corresponds with sphericity (Figure 3) and the internal structure images (Figure 2).

The number of fine pores was greater in foams with $\mathrm{I}_{\mathrm{ISO}}=200$, than in $\mathrm{I}_{\mathrm{ISO}}=300$ (Figure 5) . The biopolyol addition caused slightly more equal distribution of volumes, with less fine pores $\left(\mathrm{V}<0.005 \mathrm{~mm}^{3}\right)$ and more midsize volumes $\left(0.005 \mathrm{~mm}^{3}<\mathrm{V}<0.015 \mathrm{~mm}^{3}\right)$.

Very similar tendency occurred for pore surfaces; however, the influence of biopolyol was stronger for $\mathrm{I}_{\mathrm{ISO}}=300$ (Figure 6). This clearly indicates that the pore shape changed (the volumes remain similar, while surface decreased — though the sphericity increased).

The pore structure is also presented in horizontal sections in Figure 7, where, in particular, the pore diameter changes may be observed. The presence of biopolyol always decreased the diameters. It is more clearly visible for foams with $\mathrm{I}_{\mathrm{ISO}}=300$. Again, these images correspond with previously presented quantitative results of pore volumes and surface.

Even though the histograms of pores distribution suggest that the fine pores constitute the majority of the specimen, in fact, the cumulated large pores volume is greater. This dependency is clearly visible for pores grouped according to their diameters (Figure 8). 


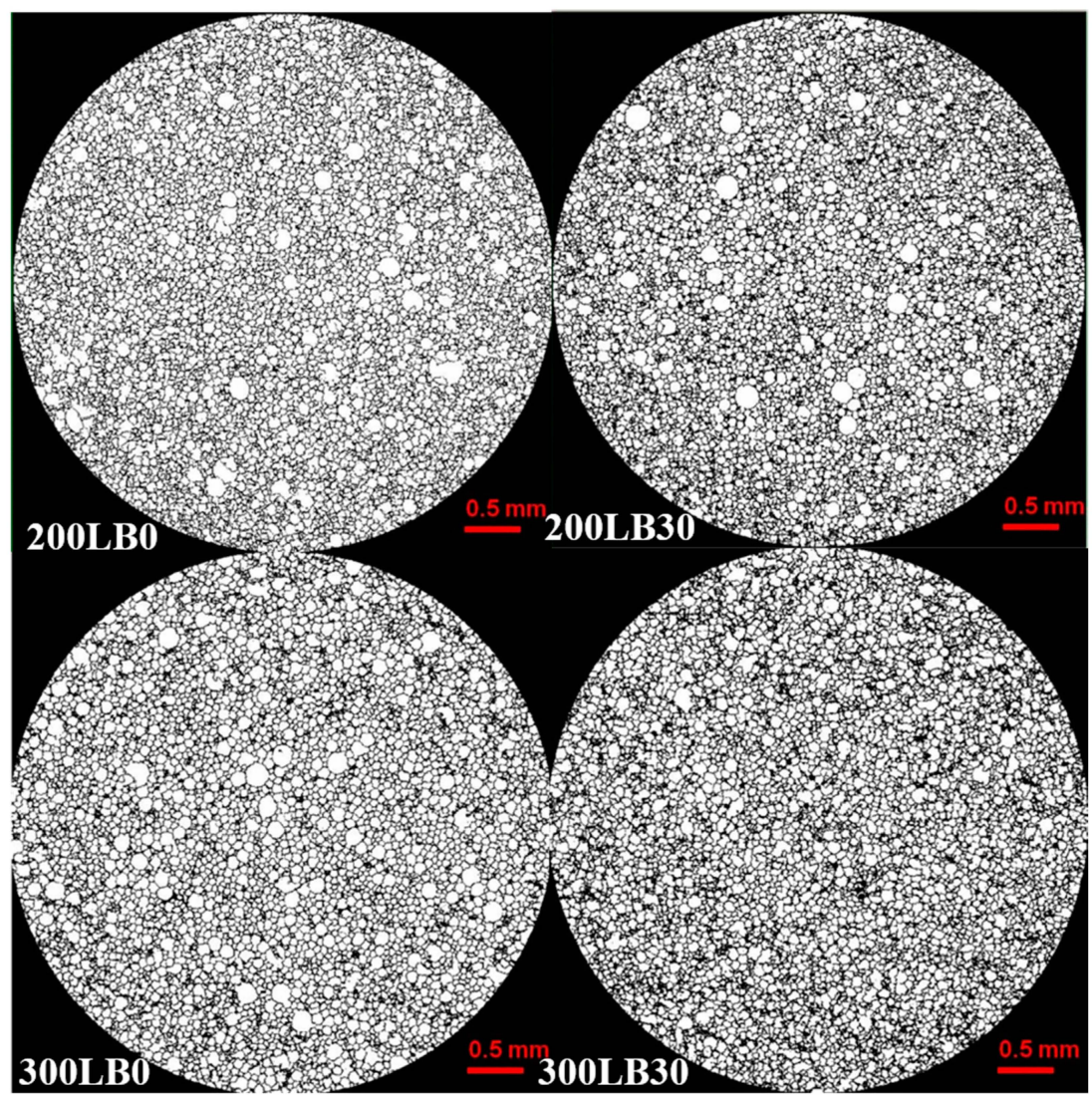

Figure 7. Midsection microCT scans after reconstruction and after watershed operation of anisotropic diffusion of specimens.

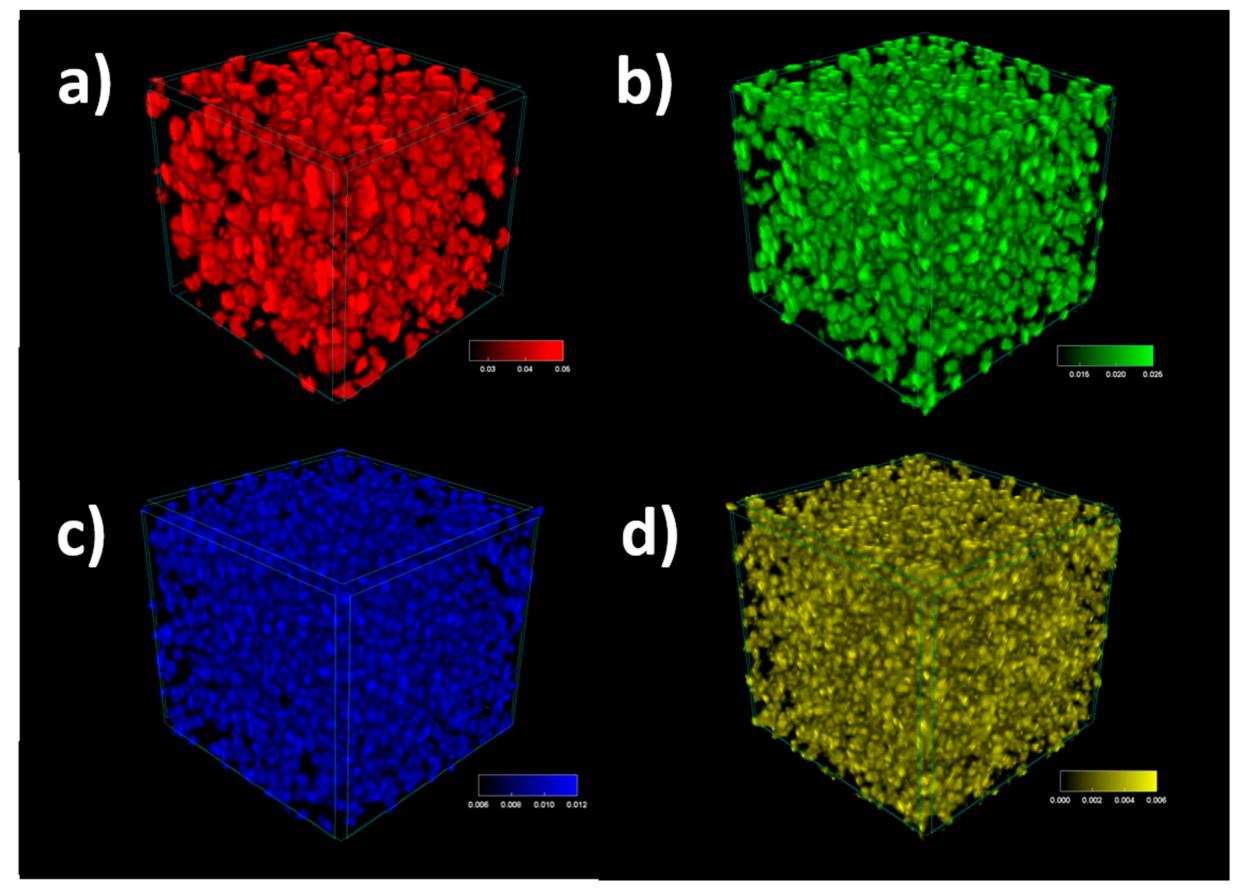

Figure 8. Pore distribution for specimen 300LB30, with the pore diameter of (a) $d>25 \mu \mathrm{m}$, (b) $25 \mu \mathrm{m}>$ $d>12 \mu \mathrm{m}$, (c) $12 \mu \mathrm{m}>d>6 \mu \mathrm{m}$ and (d) $d<6 \mu \mathrm{m}$. 


\subsection{Influence of Microstructure on Macroscopic Properties}

Depending on the apparent density, rigid polyurethane foams may have different properties, so it is important to analyze materials with similar apparent density. In order to obtain materials with a similar apparent density, with the increase of the $\mathrm{I}_{\mathrm{ISO}}$, a larger amount of blowing agent ( $n$-pentane) and a catalyst responsible for the formation of isocyanurate rings were added to the systems. The apparent density of foams in the range $49.2-52.1 \mathrm{~kg} / \mathrm{m}^{3}$ was obtained. Table 3 presents the apparent density, average values of pore diameter (SEM and microCT), thermal conductivity coefficient and thermal resistance of rigid PU foams.

The change in pore diameter for foams containing $30 \mathrm{wt} . \%$ LB biopolyol compared to the foams obtained from the petrochemical polyol is not large and falls within the error limit. The larger isocyanate index caused a slight increase in the pore diameter, which could have been due to the greater amount of blowing agent used. The introduction of LB biopolyol into foam formulations resulted in changes in the shape of the cells, as shown in Figure 9.

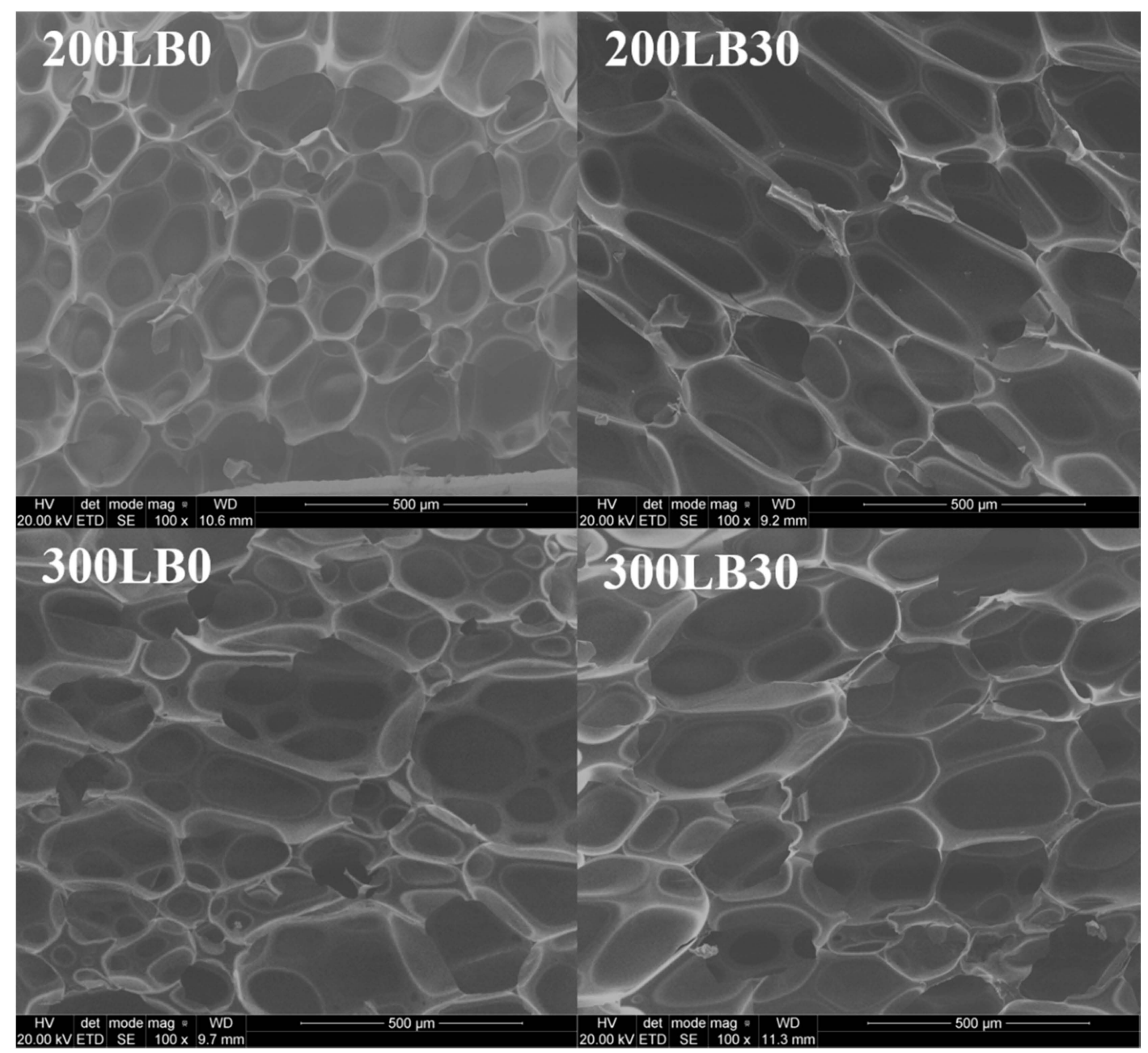

Figure 9. SEM of rigid polyurethane foams.

For foams with $\mathrm{IISO}_{\mathrm{ISO}} 200$ together with the increase of LB biopolyol content in the formulation, the cells were observed to grow towards the foam growth, which could have been caused by a higher temperature during synthesis [55]. Foams containing the LB biopolyol obtained at $\mathrm{I}_{\text {ISO }}=300$ showed a similar cell shape compared to the foam obtained from the petrochemical polyol, which could be caused by a relatively small amount of biopolyol in the foam mass (max $30 \mathrm{wt}$ \%). Hejna et al. [56] noted that significant changes in the shape of cells are only observed for about $50 \mathrm{wt} . \%$ content of 
biopolyol obtained from waste glycerol. The pore diameter values determined using $\mu \mathrm{CT}$ differ from those obtained using SEM. The differences in these values may result from:

- $\quad$ more pores analyzed by the $\mu \mathrm{CT}$ technique (10000), compared to SEM (100);

- incorrect pore division in anisotropic diffusion process in the case of $\mu \mathrm{CT}$.

The results from SEM indicate that the addition of LB biopolyol to foam formulations causes an increase in pore diameter, and the results obtained from $\mu \mathrm{CT}$ suggest an inverse relationship. However, it should be noted that, using micro CT technique, the differences in pore diameters are small and fall within the error range. This could be partially caused by the anisotropic diffusion image processing.

Table 3 also presents thermal insulation properties of foams, which are described in the form of thermal conductivity coefficient $(\lambda)$ and thermal resistance (Equation (1)). These parameters determine the potential application possibilities of PU foams as thermal insulation materials.

In the case of PU foams, the following factors enter the value of the coefficient $\lambda_{\text {gas }}, \lambda_{\mathrm{PU}}, \lambda_{\text {radiation }}$

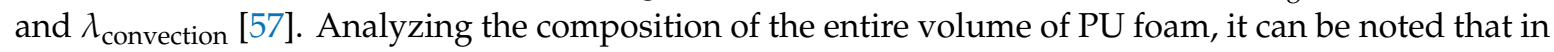
the case of materials with lower apparent density the most important parameter affecting the $\lambda$ value is the gas contained in the pores (more precisely $\lambda_{\text {gas }}$ ). Parameters affecting the thermal conductivity coefficient are also the shape and content of closed cells. It has been found that as the size of the cells increases, the value of the coefficient $\lambda$. The type of cells (closed or open) affects the convective heat transfer in the foam. The increase in the content of closed cells limits the heat movement hindering gas exchange between volatile hydrocarbons and air, so for materials with a high content of closed cells the conduction coefficient associated with convection is omitted [58]. With the increase of LB biopolyol content, a reduction in the $\lambda$ coefficient of $0.0024 \mathrm{~W} /(\mathrm{m} \cdot \mathrm{K})$ and $0.0013 \mathrm{~W} /(\mathrm{m} \cdot \mathrm{K})$ was observed, respectively for foams with an isocyanate index of 200 and 300. The largest decrease in the value of the coefficient $\lambda$ was observed for $\mathrm{I}_{\mathrm{ISO}}=200$, which may have been caused by an increase in cell dimensions that was filled with a blowing agent with a low coefficient of $\lambda=15 \mathrm{~W} /(\mathrm{m} \cdot \mathrm{K})$.

\section{Conclusions}

The presented results indicate that the addition of biopolyol obtained in the liquefaction process of biomass from the Baltic Sea (LB) to rigid polyurethane foams allows obtaining materials with improved strength and thermal resistance comparing to petrochemical foams. Rigid polyurethane foams obtained using $30 \mathrm{wt}$.\% LB biopolyol were characterized by a similar apparent density compared to foams without biopolyol. Therefore, the materials properties changes were achieved by internal structure modification due to formulation containing biopolyol. MicroCT was an effective tool for the study of the foams' internal structure due to very high scanning resolution and small rotation step with parallel implementation of postprocessing algorithms of whiter shade separation in 3D. The addition of biopolyol and higher IISO influenced the shape and size of the pores. PU foams with biopolyol had smaller average pores diameter for both $\mathrm{I}_{\mathrm{ISO}}$ and more elongated shape compared to petrochemical foams. This was most probably caused by higher synthesis temperature. Moreover, for the higher $\mathrm{I}_{\mathrm{ISO}}$, the average pore diameter increased, which was caused by a larger amount of blowing agent in the formulation. The lowest coefficient of heat transfer was characterized as $0.0246 \mathrm{~W} / \mathrm{m}^{2} \mathrm{~K}$ for foam 200_LB30.

Author Contributions: Conceptualization, P.K. (Paulina Kosmela) and Ł.P.; methodology, J.S.; software, P.K. (Paulina Kosmela); validation, K.F., J.T.H.; formal analysis, J.S., K.F. and P.K. (Paweł Kazimierski); investigation, P.K. (Paulina Kosmela) and Ł.P.; resources, P.K. (Paulina Kosmela); data curation, J.S.; writing-original draft preparation, P.K. (Paulina Kosmela) and J.S.; writing—review and editing, P.K. (Paulina Kosmela), J.S., K.F. and P.K. (Paweł Kazimierski); visualization, J.S.; supervision, J.T.H.; project administration, P.K. (Paulina Kosmela) and Ł.P.; funding acquisition, J.T.H. All authors have read and agreed to the published version of the manuscript.

Funding: This research received no external funding

Acknowledgments: The authors would like to acknowledge the support of Łukasz Skarżyński in microCT scans performing and analysis.

Conflicts of Interest: The authors declare no conflict of interest 


\section{References}

1. Agence de l'Environnment et de la Maitrise de l'Energie. Panorama du Marché du Polyuréthane et État de L'art de Sestechniques de Recyclage; ADEME: Angers, France, 2014.

2. Padopoulos, A.M. State of the art in thermal insulation materials and aims for future developments. Energy Build. 2005, 37, 77-86. [CrossRef]

3. Villasmil, W.; Fischer, L.J.; Worlitschek, J. A review and evaluation of thermal insulation materials and methods for thermal energy storage systems. Renew. Sustain. Energy Rev. 2019, 103, 71-84. [CrossRef]

4. Prociak, A. Properties of polyurethane foams modified with natural oil-based polyols. Cell. Polym. 2007, 26, 381-392. [CrossRef]

5. Pawlik, H.; Prociak, A.; Pielichowski, J. Synthesis of polyols from palm oil intended for obtaining elastic polyurethane foams. Czas. Tech. 2009, 106, 111-117.

6. Yeganeh, H.; Mehdizadeh, M.R. Synthesis and properties of isocyanate curable millable polyurethane elastomers based on castrol oil as a renewable resource polyol. Eur. Polym. J. 2004, 40, 1233-1238. [CrossRef]

7. Zimmermann, M.V.G.; Turella, T.C.; Santana, R.M.C.; Zattera, A.J. The influence of wood flour particle size and content on the rheological, physical, mechanical and morphological properties of EVA/wood cellular composites. Mater. Des. 2014, 57, 660-666. [CrossRef]

8. Hejna, A.; Kosmela, P.; Klein, M.; Formela, K.; Kopczyńska, M.; Haponiuk, J.T.; Piszczyk, Ł. Two-step conversion of crude glycerol generated by biodiesel production into biopolyols: Synthesis, structural and physical chemical characterization. J. Polym. Environ. 2018, 26, 3334-3344. [CrossRef]

9. Dhaliwala, G.S.; Anandana, S.; Chandrashekharaa, K.; Leesb, J.; Namb, P. Development and characterization of polyurethane foams with substitution of polyether polyol with soy-based polyol. Eur. Polym. J. 2018, 107, 105-117. [CrossRef]

10. Pott, R.V.M.; Howe, C.J.; Dennis, J.S. The purification of crude glycerol derived from biodiesel manufacture and its use as a substrate by Rhodopseudomonas palustris to produce hydrogen. Bioresour. Technol. 2014, 152, 464-470. [CrossRef]

11. Petrov, K.; Petrova, P. Enhanced production of 2,3-butanediol from glycerol by forced $\mathrm{pH}$ fluctuations. Appl. Microbiol. Biotechnol. 2010, 87, 943-949. [CrossRef]

12. Ionescu, M.; Petrović, Z.S. High functionality polyether polyols based on polyglycerol. J. Cell. Plast. 2010, 46, 223-237. [CrossRef]

13. Liang, L.; Mao, Z.; Li, Y.; Wan, C.; Wang, T.; Zhang, L. Liquefaction of crop residues for polyol production. BioResources 2006, 1, 1-9. [CrossRef]

14. Hassan, E.; Shurky, N. Polyhydric alcohol liquefaction of some lignocellulosic agricultural residues. Ind. Crops Prod. 2008, 27, 33-38. [CrossRef]

15. Soares, B.; Gama, N.; Frerie, C.; Barros-Timmons, A.; Brandão, I.; Silva, R.; Neto, C.P.; Ferreira, A. Ecopolyol production from industrial cork powder via acid liquefaction using polyhydric alcohols. ACS Sustain. Chem. Eng. 2014, 2, 846-854. [CrossRef]

16. Ohara, H. Biorefinery. Appl. Microbiol. Biotechnol. 2003, 62, 474-477. [CrossRef]

17. Kuruppalil, Z. Green plastics: An emerging alternative for petroleum-based plastics. Int. J. Eng. Res. Innov. 2011, 3, 59-63.

18. Pathak, S.; Sneha, C.L.R.; Mathew, B.B. Bioplastics: Its timeline based scenario \& challenges. J. Polym. Biopolym. Phys. Chem. 2014, 2, 84-90.

19. Idrus, N.F.; Manshor, N.M.; Davis, B.G. Surface morphology and mechanical properties of chitosan film incorporated with marine macroalgae by casting method. Appl. Mech. Mater. 2014, 575, 26-30. [CrossRef]

20. Albano, C.; Karam, A.; Dominguez, N.; Sanchez, Y.; Gonzalez, J.; Aguirre, O.; Catano, L. Thermal, mechanical, morphological, thermogravimetric, rheological and toxicological behavior of HDPE/seaweed residues composites. Compos. Struct. 2005, 71, 282-288. [CrossRef]

21. Jang, Y.H.; Han, S.O.; Sim, I.N.; Kim, H. Pretreatment effects of seaweed on the thermal and mechanical properties of seaweed/polypropylene biocomosites. Compos. Part A Appl. Sci. Manuf. 2013, 47, 83-90. [CrossRef]

22. Algix. LLC. Available online: http://algix.com/products-services/solaplast-resin-grades/ (accessed on 1 September 2020). 
23. Oh, S.T.; Kim, S.H.; Jeong, H.Y.; Lee, J.M.; Cho, J.W.; Park, J.S. The mechanical properties of polyurethane foam wound dressing hybridized with alginate hydrogel and jute fiber. Fibers Polym. 2013, 14, $173-181$. [CrossRef]

24. Yun, J.K.; Yoo, H.J.; Kim, H.D. Preparation and properties of waterborne polyurethane-urea/sodium alginate blends for high water vapor permeable coating materials. J. Appl. Polym. Sci. 2007, 105, 1168-1176. [CrossRef]

25. Yuvarani, I.; Senthilkumar, S.; Venkatesan, J.; Kim, S.H.; Al-Kheraif, A.A.; Anil, S.; Sudha, P.H. Chitosan modified alginate-polyurethane scaffold for skeletal muscle tissue engineering. J. Biomater. Tissue Eng. 2015, 5, 665-672. [CrossRef]

26. Chen, H.B.; Shen, P.; Chen, M.J.; Zhao, H.N.; Schiraldi, D.A. Highly efficient flame retardant polyurethane foam with alginate/clay aerogel coating. ACS Appl. Mater. Interfaces 2016, 8, 32557-32564. [CrossRef]

27. Kwon, O.J.; Oh, S.T.; Lee, S.D.; Lee, N.R.; Shin, C.H.; Park, J.S. Hydrophilic and flexible polyurethane foams using sodium alginate as polyol: Effects of PEG molecular weight and cross-linking agent content on water absorbency. Fibers Polym. 2007, 8, 347-355. [CrossRef]

28. Pawar, M.S.; Kadam, A.S.; Daeane, B.S.; Yemul, O.S. Synthesis and characterization of rigid polyurethane foams from algae oil using biobased chain extenders. Polym. Bull. 2016, 73, 727-741. [CrossRef]

29. Kim, K.H.; Jo, Y.M.; Lee, C.G.; Lee, E. Solvothermal liquefaction of microalgal Tetraselmis sp. Biomass to prepare biopolyols by using PEG\#400-blended glycerol. Algal. Res. 2015, 12, 539-544.

30. Coppola, O.; Magliulo, G.; Di Maio, E. Mechanical characterization of a polyurethane-cement hybrid foam in compression, tension, and shear. ASCE J. Mater. Civ. Eng. 2017, 29, 1-8. [CrossRef]

31. Pauwels, E.; Van Loo, D.; Cornillie, P.; Brabant, L.; Van Hoorebeke, L. An exploratory study of contrast agents for soft tissue visualization by means of high-resolution X-ray computed tomography imaging. J. Microsc. 2013, 250, 21-31. [CrossRef]

32. Sampath, T.K.; Simic, P.; Sendak, R.; Draca, N.; Bowe, A.E.; O’Brien, S.; Schiavi, S.C.; McPherson, J.M.; Vukicevic, S. Thyroid-stimulating hormone restores bone volume, microarchitecture, and strength in aged ovariectomized rats. J. Bone Miner. Res. 2007, 22, 849-859. [CrossRef]

33. Cantre, D.; Herremans, E.; Verboven, P.; Ampofo-Asiama, J.; Nicolai, B.M. Characterization of the 3-D microstructure of mango (Mangifera indica L. cv. Carabao) during ripening using X-ray computed microtomography. Innov. Food Sci. Emerg. Technol. 2014, 24, 28-39. [CrossRef]

34. Tuan, H.S.; Hutmacher, W. Application of micro-CT and computation modeling in bone tissue engineering. Comput. Aided Des. 2005, 37, 1151-1161. [CrossRef]

35. Tilman, D.; Pfeiffer, F.; Bunk, O.; Grunzweig, C.; Hempel, E.; Popescu, S.; Vock, P.; David, C. Toward clinical $\mathrm{X}$-ray phase-contrast CT: Demonstration of enhanced soft-tissue contrast in human specimen. Invest. Radiol. 2010, 45, 445-452.

36. Otani, J.; Watanabe, Y.; Chevalier, B. Introduction of X-ray CT application in geotechnical engineering-Theory and practice. In Proceedings of the IOP Conference Series: Materials Science and Engineering, 9th World Congress on Computational Mechanics and 4th Asian Pacific Congress on Computational Mechanics, Sydney, Australia, 19-23 July 2010.

37. Besuell, P.; Viggiani, G.; Lenoir, N.; Desrues, J.; Bornert, M. X-ray micro CT for studying strain localization in clay rocks under triaxial compression. In Proceedings of the GEOX 2006-2nd International Workshop on X-ray CT for Geomaterials, Aussois, France, 4-7 October 2006; pp. 35-52.

38. Skarżyński, Ł.; Tejchman, J. Experimental investigations of fracture process in concrete by means of X-ray micro-computed tomography. Strain 2016, 52, 26-45. [CrossRef]

39. Suchorzewski, J.; Nitka, M.; Tejchman, J. Experimental and numerical investigations of concrete behaviour at meso-level during quasi-static splitting tension. Theor. Appl. Fract. Mech. 2018, 96, 720-739. [CrossRef]

40. Skarżyński, Ł.; Suchorzewski, J. Mechanical and fracture properties of concrete reinforced with recycled and industrial steel fibers using Digital Image Correlation technique and X-ray micro computed tomography. Constr. Build. Mater. 2018, 183, 283-299. [CrossRef]

41. Kazimierski, P.; Vieira, S.; Kardaś, D. Pine wood particle pyrolysis and radiographic analysis. Drv. Ind. 2020, 71, 13-18. [CrossRef]

42. Patterson, B.M.; Henderson, K.; Gilbertson, R.D.; Tornga, S.; Cordes, N.L.; Chavez, M.E.; Smith, Z. Morphological and performance measures of polyurethane foams using X-ray CT and mechanical testing. Microsc. Microanal. 2014, 20, 1284-1293. [CrossRef] 
43. Adrien, J.; Maire, E.; Gimenez, N.; Sauvant-Moynot, V. Experimental study of the compression behaviour of syntactic foams by in situ X-ray tomography. Acta Mater. 2007, 55, 1667-1679. [CrossRef]

44. McDonald, S.M.; Dedreuil-Monet, G.; Yao, Y.T.; Alderson, A.; Withers, P.J. In situ 3D X-ray microtomography study comparing auxetic and non-auxetic polymeric foams under tension. Phys. Status Solidi B 2011, 248, 45-51. [CrossRef]

45. Youssef, S.; Maire, E.; Gaertner, R. Finite element modelling of the actual structure of cellular materials determined by X-ray tomography. Acta Mater. 2005, 53, 719-730. [CrossRef]

46. Paciorek-Sadowska, J.; Borowicz, M.; Czupryński, B.; Liszkowska, J. Kompozyty sztywnych pianek poliuretanowo-poliizocyjanurowych z kora dębu szypułkowego. Polimery 2017, 62, 666-672. [CrossRef]

47. Kosmela, P.; Gosz, K.; Kazimierski, P.; Hejna, A.; Haponiuk, J.T.; Piszczyk, Ł. Chemical structures, rheological and physical properties of biopolyols prepared via solvothermal liquefaction of Enteromorpha and Zostera marina biomass. Cellulose 2019, 26, 5893-5912. [CrossRef]

48. Hejna, A.; Haponiuk, J.; Piszczyk, Ł.; Klein, M.; Formela, K. Performance properties of rigid polyurethanepolyisocyanurate/brewers' spent grain foamed composites as function of isocyanate index. e-Polymers 2017, 17, 427-437. [CrossRef]

49. Zatorski, W.; Brzozowski, Z.K.; Kolbrecki, A. New developments in chemical modification of fire-safe rigid polyurethane foams. Polym. Degrad. Stabil. 2008, 93, 2071-2076. [CrossRef]

50. Modesti, M.; Lorenzetti, A. An experimental method for evaluating isocyanate conversion and trimer formation in polyisocyanate-polyurethane foams. Eur. Polym. J. 2001, 37, 949-954. [CrossRef]

51. Skarżyński, Ł.; Korol, E.; Tejchman, J. Measurements and calculations of the width of the fracture process zones on the surface of notched concrete beams. J. Strain Anal. Eng. Des. 2011, 47, 319-332. [CrossRef]

52. Crica, L.E.; Wengenroth, J.; Tiainen, H.; Ionita, M.; Haugen, H.J. Enhanced X-ray absorption for micro-CT analysis of low-density polymers. J. Biomater. Sci. 2016, 27, 805-823. [CrossRef]

53. Nacucchi, M.; De Pascalis, F.; Scatto, M.; Capodieci, L.; Albertoni, R. Structural analysis of advanced polymeric foams by means of high-resolution X-ray computed tomography. AIP Conf. Proc. 2016, 1749, 020009.

54. Wadell, H. Volume, shape and roundness of quartz particles. J. Geol. 1935, 43, 250-280. [CrossRef]

55. Zieleniewska, M.; Leszczyński, M.K.; Kurańska, M.; Prociak, A.; Szczepkowski, L.; Krzyżowska, M.; Ryszkowska, J. Preparation and characterisation of rigid polyurethane foams using a rapeseed oil-based polyol. Ind. Crops Prod. 2015, 74, 887-897. [CrossRef]

56. Hejna, H.; Kosmela, P.; Kirpluks, M.; Cabulis, U.; Klein, M.; Haponiuk, J.T.; Piszczyk, Ł. Mechanical, thermal and fire behavior assessments of environmentally friendly crude glycerol-based rigid polyisocyanurate foams. J. Polym. Environ. 2018, 26, 1854-1868. [CrossRef]

57. Szycher, M. Szycher's Handbook of Polyurethanes; CRC Press: Boca Raton, FL, USA, 1999.

58. Bogdan, M.; Hoerter, J.; Moore, F.O. Meeting the insulation requirements of the building envelope with polyurethane and polyisocyanurate foam. J. Cell. Plast. 2005, 41, 41-56. [CrossRef]

Publisher's Note: MDPI stays neutral with regard to jurisdictional claims in published maps and institutional affiliations.

(C) 2020 by the authors. Licensee MDPI, Basel, Switzerland. This article is an open access article distributed under the terms and conditions of the Creative Commons Attribution (CC BY) license (http://creativecommons.org/licenses/by/4.0/). 